\title{
ブロイラー・ヒナ仕上期におけるリボフラビン およびニコチン酸の要求量
}

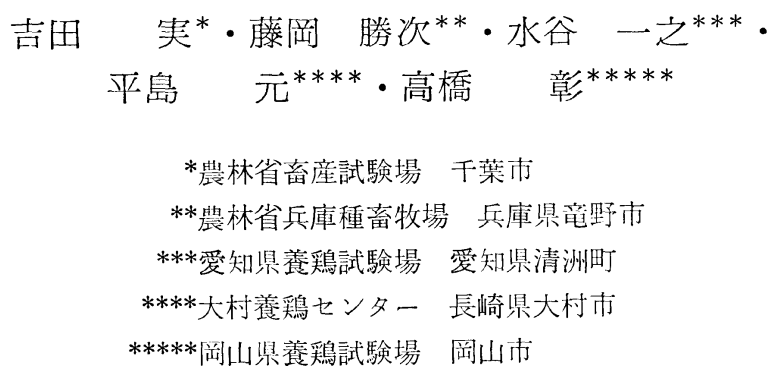

わが国に，ブロイラーに適した鷄種として白色コーニ ッシュ種 (WC と略す) や白色プリマスロック種 (WR と略す）が導入された当初，飼料中のビタミン含量に問 題があり，ヒナに脚弱症状が発生する例が多かった。同 一飼料を与えた在来の卵用種ヒナに注問題がないことか ら, これら肉専用種のビタミンの要求量が, 卵用種より 多いことが予想されていたが，これは，肉專用種ヒナを 用いる一連の研究によって確認された1 3)。しかしこれ は 3 週令までの幼いヒナによる研究であって, この結果 安 4 週令以後の，仕上期のブロイラーに適用することの 適否は，保証されていない。

畜産試験場における研究成績（未発表）によれば，4 週令以後には, ビタミンの要求量は急激に減少すること が示唆されている。この示唆は, 蛋白質4) およびリン51 の要求量が，3〜4 週令の時期を境にして減小するとい う征来の知見からみて，大いにありうることであらう。

この示唆を実際的な条件の下に検討する目的をもっ て, 愛知県養鵎試験場, 長崎県養鷄センターおよび岡山 県養鵎試験場と協同して，大羽数を用いる飼養試験を実 施するとともに，祳林省兵庫種畜牧場において，実用的 な飼料にビタミンを添加しない場合について，ブロイラ 一の発育成績在検討した。

\section{実験材料および方法}

ヒナおよび飼育法：供試したヒナはすべて一代雑種で あって，いずれも WC を父親としている。母親として は, 愛知県養鵎試験場では WR $\left(\mathrm{F}_{1}\right.$ を $\mathrm{WC} \times \mathrm{WR}$ で示 す), 長崎県養鷄センターでは, 横斑プリマスロック種 (BP と略し， $\mathrm{F}_{1}$ を WC $\times \mathrm{BP}$ で示す), また, 岡山県養 鷄試験場では, ニューハンプシャ一種 $\left(\mathrm{NH}\right.$ と略し, $\mathrm{F}_{1}$

趴和 42 年 3 月 28 日受付
は $\mathrm{WC} \times \mathrm{NH}$ で示す）をそれぞれ用いている。ヒナは各 試験場に打いて，それぞれの県下で市販されているも。 のまたは自場において生産したものを供試している。 兵庫種畜牧場では, 同場で生産した $\mathrm{WC} \times \mathrm{WR}$ を供試し たが，その場合母親の WR として，同場の A 系のも. のを用いた $\mathrm{F}_{1}$ と $\mathrm{J}$ 系のものを用いた $\mathrm{F}_{1}$ を，同数ずつ 混合して飼育し，ビタミンの効果と同時に，母親，WR の系統間の相違もあわせて検討できるように計画した。

愛知, 長崎, 岡山の各試験場では, 雄初生ヒナ 50 羽, 抢よび雌初生ヒナ 50 羽を 1 区とする 5 区ずつを供試し た。最初の 4 週間は共通の初生用飼料を与光, その後, 仕上用の試験飼料に切替えたが，そのときに，岡山では， 淘汰して雄, 雌各 46 羽ずつとした。兵庫種畜牧場では, $\mathrm{WC} \times \mathrm{WR}(\mathrm{A}$ 系) と $\mathrm{WC} \times \mathrm{WR}(\mathrm{J}$ 系) をそれぞれ雄此: 各 10 羽ずつを 1 区とする 6 区を設定して試験した。 したがって，1区 40 羽，総羽数 240 羽を供試してい る。4 試験場において供試した総羽数は 1,740 羽であ る。

初生ヒナは, 各試験場において, 育すう器に収容し て，共通の初生用飼料を与えて 4 週間飼育した。その 後, 試験用飼料にかえて, それ以後 10 週令字で, 6 週 間にわたって試験した。この間，1 週間ごとに体重と飼 料湶取量を測定した。

試験期間中の飼育管理力法の詳細は, 各試験場の慣行 によったが, 最小限度の必要事項は, 事前に申合せ宏行 って,できるだけ統一した。その細目に関しては既報防. のようである。

供試飼料：供試した基礎飼料の組成を表 1 亿示した。 この基礎飼料汁仕上用として 4 週令以後に与えたもの で，表の組成のもの $97.5 \%$ に，表 2 に示したビタミン B 添加剂 0 5 号をそれぞれ $2.5 \%$ ずっ配合して試験飼， 料 0 ５定調製した。初生ヒナには，4週令まで共通の 
表 1 仕上用基礎飼料組成 ${ }^{11}$

\begin{tabular}{|c|c|}
\hline 成 分 & 含 \\
\hline トウモロコシ & $76.73^{\%}$ \\
\hline 魚粉 & 5.03 \\
\hline 大 豆粕 & 13.00 \\
\hline 炭酸カルシウム & 1.50 \\
\hline リン酸 2 カルシウム & 0.50 \\
\hline 食塩 & 0.45 \\
\hline 微量無機添加 剂2) & 0.05 \\
\hline ビタミン $\mathrm{A}, \mathrm{D}$ 剂2) & 0.10 \\
\hline コクシジウム予防剂2) & 0.04 \\
\hline 抗 生 物 質 & 0.10 \\
\hline
\end{tabular}

1）基礎飼料 $97.5 \%$ に表 2 のビタミンB剤 $2.5 \%$ を 加えて $100 \%$ になる。

2) 文献 8 参照。
屠体成分分析：10 週間の試験終了後, あらかじめ申 合せた方法6)によって, 枝肉, 可食内蔵（筋胃，心蔵お よび肝臓）および精肉の歩留を測定した。

\section{実 験 結 果}

愛知, 長崎, 岡山の各試験場における仕上用基礎飼料 中のリボフラビンとニコチン酸の測定值を表 3 に示し た。リボフラビン含量はよく一致していたが、ニコチン 酸含量にはかなりの变動がみられる。基礎飼料は同一飼 料工場で配合したものを分配しているので，これらの測 定值間の変動はサンプル間の変動と考えられる。そこ で, 3 場の測定值間の平均值をもって基礎飼料中の含量 とみなし，これにビタミンB添加剤に由来する添加量を 加えて, 試験飼料中のリボフラビン, ニコチン酸の含量 とした。また，兵庫種畜牧場において供試した基礎飼料

表 2 ビ タ ミン B 添加剂組成 1)

\begin{tabular}{|c|c|c|c|c|c|c|}
\hline 添加剂番 号 & 0 & 1 & 2 & 3 & 4 & 5 \\
\hline リボフ ラビン & $\mathrm{mg} / \mathrm{kg}$ & $\underset{48}{\mathrm{mg} / \mathrm{kg}}$ & $\begin{array}{c}\mathrm{mg} / \mathrm{kg} \\
48\end{array}$ & $\begin{array}{c}\mathrm{mg} / \mathrm{kg} \\
220\end{array}$ & $\underset{364}{\mathrm{mg} / \mathrm{kg}}$ & $\underset{364}{\mathrm{mg} / \mathrm{kg}}$ \\
\hline 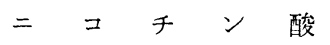 & - & 160 & 1,360 & 600 & 160 & 1,360 \\
\hline チ $\quad$ ア & 80 & & & & & \\
\hline パントテン酸カルシウム & 218 & & & & & \\
\hline ピリドキシン & 80 & 同左 & 同左 & 同左 & 同左 & 同左 \\
\hline 葉 & 40 & & & & & \\
\hline 塩 化 $コ$ リ & 5,520 & & & & & \\
\hline
\end{tabular}

1）コーンスターチを加えて $1 \mathrm{~kg}$ になるようにする。 基礎飼料に $2.5 \%$ の割合で配合する。

初生用飼料を与えて飼育したが，その組成は前報》の表 1 に示した組成と同じものであって，その粗蛋白質およ び可消化養分総量は，それぞれ $20 \%$ と $68 \%$ になるよ うに調製している。また，表 1 の仕上用飼料では，それ ぞれ $16 \%$ と $73 \%$ になるように調節しているが，これ らの蛋白質やエネルギーの含量は，いずれもブロイラー の飼養標準として推奨した含量 ${ }^{81}$ に等しい。

初生用飼料および仕上用基礎飼料注, 飼料会社に, ま たビタミンB添加剤は, 添加用メーカーに, それぞれ依 託して製造し，各試験場に配布した。各試験場におい て，仕上用基礎飼料 $97.5 \%$ にビタミン添加剤 $2.5 \%$ を 配合して試験飼料とした。各試験場に配布した仕上用基 礎飼料中のリボフラビンとニュチン酸含量は, それぞれ 微生物定量法9により測定した。

なお，6 種類のビタミン添加剤は，リボフラビンとニ コチン酸の含量を異にしているほかは, 同一組成であっ て，飼料中に $2.5 \%$ 配合することにより，チォミン以下 の 5 種類のビタミンを，十分に含むようにした。
表 3 基礎飼料中のビタミン含量

\begin{tabular}{|c|c|c|c|}
\hline 試 験 & 場 & リボフラビン & ニコチン酸 \\
\hline 愛 & 知 & $\begin{array}{c}\mathrm{mg} / \mathrm{kg} \\
1.4\end{array}$ & $\begin{array}{c}\mathrm{mg} / \mathrm{kg} \\
36.0\end{array}$ \\
\hline 岡 & 山 & 1.4 & 34.8 \\
\hline 長 & 崎 & 1.4 & 42.8 \\
\hline 平 & 均 & 1.4 & 37.9 \\
\hline
\end{tabular}

は，製造時期が異なっているが，ビタミン含量の測定を 行わなかったので, 表 3 の平均值を適用して推定值とし た。

愛知県養鶏試験場における試験結果を表 4 に, 長崎県 養鶏センターにおける成績を表 5 に，岡山県養䳕試験場 における成績を表 6 に，それぞれまとめて示した。この 3 場における実験は，いずれも同一の実験計画により実 施したので，成績を合併して分散分析した結果を表 7 に まとめた。

增体量についてみれば, 性別により差が認められてい 
吉田・藤岡・水谷・平岛・高橋：ブロイラーのビタミン要求量

表 4 愛知県養鶏試験場における試験成績（舀種 WC $\times$ WR）

試験期間: 昭和 40 年 9 月 24 日〜昭和 40 年 12 月 3 日

\begin{tabular}{|c|c|c|c|c|c|c|c|c|c|c|c|}
\hline 飼 & 料 番 号 & 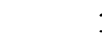 & & 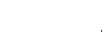 & & & 3 & & 4 & 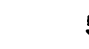 & 5 \\
\hline $\begin{array}{l}\text { リボフ } \\
\text { ニコ }\end{array}$ & $\begin{array}{lll}\text { ラビン } \mathrm{mg} / \mathrm{kg} \\
\text { チン酸 } \mathrm{mg} / \mathrm{kg}\end{array}$ & $\begin{array}{l}2 \\
4\end{array}$ & & $\begin{array}{l}2 \\
7\end{array}$ & & $\begin{array}{l}6 \\
5\end{array}$ & & 10 & & & .5 \\
\hline 性 & 別 & $\hat{o}$ & 우 & $\widehat{\delta}$ & 우 & $\hat{\delta}$ & 우 & $\hat{\delta}$ & 우 & $\hat{o}$ & 우 \\
\hline 4 週令 & $\begin{array}{l}\text { 羽 数 } \\
\text { 初 体重 } \mathrm{g}\end{array}$ & $\begin{array}{r}50 \\
446\end{array}$ & $\begin{array}{r}49 \\
427\end{array}$ & $\begin{array}{r}50 \\
448\end{array}$ & $\begin{array}{r}49 \\
427\end{array}$ & $\begin{array}{r}50 \\
448\end{array}$ & $\begin{array}{r}50 \\
429\end{array}$ & $\begin{array}{r}50 \\
448\end{array}$ & $\begin{array}{r}50 \\
427\end{array}$ & $\begin{array}{r}50 \\
448\end{array}$ & $\begin{array}{r}49 \\
427\end{array}$ \\
\hline 10週令 & $\begin{array}{l}\text { 羽 数 } \\
\text { 終体重 } \mathrm{g} \\
\text { 育成率 } \%\end{array}$ & $\begin{array}{r}49 \\
1,985 \\
98\end{array}$ & $\begin{array}{r}49 \\
1,667 \\
100\end{array}$ & $\begin{array}{r}48 \\
1,932 \\
96\end{array}$ & $\begin{array}{r}49 \\
1,657 \\
100\end{array}$ & $\begin{array}{r}49 \\
1,917 \\
98\end{array}$ & $\begin{array}{r}50 \\
1,640 \\
100\end{array}$ & $\begin{array}{r}50 \\
1,901 \\
100\end{array}$ & $\begin{array}{r}50 \\
1,634 \\
100\end{array}$ & $\begin{array}{r}50 \\
1,939 \\
100\end{array}$ & $\begin{array}{r}48 \\
1,645 \\
98\end{array}$ \\
\hline $\begin{array}{c}4 \sim 10 \\
\text { (6 週令 } \\
(6 \text { 週) }\end{array}$ & $\begin{array}{l}\text { 增体量 } \mathrm{g} \\
\text { 同上指 数 } \\
\text { 飼料摂取量 } \mathrm{g} \\
\text { 飼料要求率 }\end{array}$ & $\begin{array}{r}1,39 \\
10 \\
4,34\end{array}$ & 13 & $\begin{array}{r}1,35 \\
10 \\
4,38\end{array}$ & 3.23 & $\begin{array}{r}1,34 \\
10 \\
4,22\end{array}$ & $\begin{array}{l}0 \\
0 \\
7 \\
3.15\end{array}$ & $\begin{array}{r}1,33 \\
4,3\end{array}$ & $\begin{array}{l}0 \\
9 \\
3 \\
3.24\end{array}$ & $\begin{array}{r}1,35 \\
10 \\
4,26\end{array}$ & $\begin{array}{l}55 \\
11 \\
0 \\
3.14\end{array}$ \\
\hline $\begin{array}{l}\text { 屠 } \\
\text { 威 } \\
\text { 分 }\end{array}$ & $\begin{array}{l}\text { 技肉步留\% } \\
\text { 可食内臓\% } \\
\text { 精肉步留\% }\end{array}$ & & $\begin{array}{l}8 \\
.1 \\
.7\end{array}$ & & $\begin{array}{l}7 \\
.1 \\
6\end{array}$ & & $\begin{array}{l}8.2 \\
6.3 \\
0.9\end{array}$ & & $\begin{array}{l}7.8 \\
6.5 \\
0.7\end{array}$ & & $\begin{array}{r}6.3 \\
6.4 \\
50.1\end{array}$ \\
\hline
\end{tabular}

表 5 長崎県養鵎試験における試験成績（鷄種 $\mathrm{WC} \times \mathrm{BR}$ )

試験期間：昭和 40 年 10 月 13 日～昭和 40 年 12 月 22 日

\begin{tabular}{|c|c|c|c|c|c|c|c|c|c|c|c|}
\hline 飼 & 料 番 号 & \multicolumn{2}{|c|}{1} & \multicolumn{2}{|c|}{2} & \multicolumn{2}{|c|}{3} & \multicolumn{2}{|c|}{4} & \multicolumn{2}{|c|}{5} \\
\hline \multicolumn{2}{|c|}{$\begin{array}{l}\text { リボフラビン } \mathrm{mg} / \mathrm{kg} \\
\text { = コチン酸 } \mathrm{mg} / \mathrm{kg}\end{array}$} & \multicolumn{2}{|c|}{$\begin{array}{l}2.6 \\
42\end{array}$} & \multicolumn{2}{|c|}{$\begin{array}{l}2.6 \\
72\end{array}$} & \multicolumn{2}{|c|}{$\begin{array}{l}6.9 \\
53\end{array}$} & \multicolumn{2}{|c|}{$\begin{array}{c}10.5 \\
42\end{array}$} & \multicolumn{2}{|c|}{$\begin{array}{c}10.5 \\
72\end{array}$} \\
\hline 性 & 別 & $\widehat{o}$ & 우 & $\widehat{o}$ & 우 & $\hat{o}$ & 우 & $\hat{o}$ & 우 & $\hat{o}$ & 우 \\
\hline 4 週令 & $\begin{array}{l}\text { 羽 }{ }^{\text {数 }} \\
\text { 初 体 重 } \mathrm{g}\end{array}$ & $\begin{array}{r}50 \\
395\end{array}$ & $\begin{array}{r}50 \\
360\end{array}$ & $\begin{array}{r}50 \\
375\end{array}$ & $\begin{array}{r}48 \\
375\end{array}$ & $\begin{array}{r}50 \\
390\end{array}$ & $\begin{array}{r}50 \\
370\end{array}$ & $\begin{array}{r}50 \\
375\end{array}$ & $\begin{array}{r}49 \\
365\end{array}$ & $\begin{array}{r}50 \\
405\end{array}$ & $\begin{array}{r}50 \\
360\end{array}$ \\
\hline 10週令 & $\begin{array}{ll}\text { 羽 } & \text { 数 } \\
\text { 終 体 重 } \mathrm{g} \\
\text { 育 成率 } \%\end{array}$ & $\begin{array}{r}48 \\
1,593 \\
96\end{array}$ & $\begin{array}{r}50 \\
1,418 \\
100\end{array}$ & $\begin{array}{r}49 \\
1,662 \\
98\end{array}$ & $\begin{array}{r}47 \\
1,477 \\
98\end{array}$ & $\begin{array}{r}50 \\
1,603 \\
100\end{array}$ & $\begin{array}{r}49 \\
1,424 \\
98\end{array}$ & $\begin{array}{r}49 \\
1,664 \\
98\end{array}$ & $\begin{array}{r}49 \\
1,443 \\
100\end{array}$ & $\begin{array}{r}50 \\
1,666 \\
100\end{array}$ & $\begin{array}{r}50 \\
1,450 \\
100\end{array}$ \\
\hline 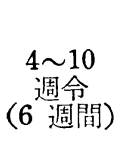 & $\begin{array}{l}\text { 增体量 } \mathrm{g} \\
\text { 同上指 数 } \\
\text { 飼料掑取量 } \mathrm{g} \\
\text { 飼料要求率 }\end{array}$ & $\begin{array}{r}1,1 \\
1 \\
3,8\end{array}$ & .40 & $\begin{array}{r}1,1 \\
1 \\
3,9\end{array}$ & .29 & $\begin{array}{r}1,1 \\
1 \\
3,8\end{array}$ & .43 & $\begin{array}{r}1,1 \\
1 \\
4,0\end{array}$ & 39 & $\begin{array}{r}1,17 \\
10 \\
3,93\end{array}$ & $\begin{array}{l}6 \\
4 \\
2 \\
3.34\end{array}$ \\
\hline $\begin{array}{l}\text { 屠 } \\
\text { 盛 } \\
\text { 分 }\end{array}$ & $\begin{array}{l}\text { 技肉歩留\% } \\
\text { 可食内臓\% } \\
\text { 精肉步留\% }\end{array}$ & $\begin{array}{r}69.1 \\
6.4 \\
46.6\end{array}$ & $\begin{array}{r}68.9 \\
5.4 \\
52.0\end{array}$ & $\begin{array}{r}69.4 \\
5.3 \\
48.6\end{array}$ & $\begin{array}{r}67.8 \\
5.5 \\
49.0\end{array}$ & $\begin{array}{r}66.5 \\
5.2 \\
46.5\end{array}$ & $\begin{array}{r}67.1 \\
5.8 \\
49.3\end{array}$ & $\begin{array}{r}67.0 \\
5.5 \\
49.6\end{array}$ & $\begin{array}{r}67.5 \\
5.3 \\
48.7\end{array}$ & $\begin{array}{r}66.8 \\
5.7 \\
46.7\end{array}$ & $\begin{array}{r}66.0 \\
6.1 \\
48.6\end{array}$ \\
\hline
\end{tabular}

るほか, 場間差が有意であって，愛知で供試した WCX WR の成績が他の 2 鷄種よりすぐれていた。これは, 従来の知見と一致しているが，しかし，この鵎種間差に は，気候条件の差異などの環境条件その他種々の原因に よる場間差が交絡していることを考慮する必要がある。
これは, 増体量の性・場間交互作用効果および, 飼料要 求率の場間差についても同様であって, その生物学的な 意義について断定的な結論は差控えるべきである。

これに対し, 飼料間差は, 増体量, 飼料要求率ともに 有意とはいえなかった。飼料・場および飼料・性の各交 
表 6 岡山県養鷄試験場における試験成績（鷄種 $\mathrm{WC} \times \mathrm{NH}$ )

試験期間：昭和 40 年 10 月 5 日～昭和 40 年 12 月 14 日

\begin{tabular}{|c|c|c|c|c|c|c|c|c|c|c|c|}
\hline 飼 & 料 番 号 & \multicolumn{2}{|c|}{1} & \multicolumn{2}{|c|}{2} & \multicolumn{2}{|c|}{3} & \multicolumn{2}{|c|}{4} & \multicolumn{2}{|c|}{5} \\
\hline \multicolumn{2}{|c|}{$\begin{array}{l}\text { リボフラビン } \mathrm{mg} / \mathrm{kg} \\
\text { ニコチン酸 } \mathrm{mg} / \mathrm{kg}\end{array}$} & \multicolumn{2}{|c|}{$\begin{array}{l}2.6 \\
42\end{array}$} & \multicolumn{2}{|c|}{$\begin{array}{l}2.6 \\
72\end{array}$} & \multicolumn{2}{|c|}{$\begin{array}{l}6.9 \\
53\end{array}$} & \multicolumn{2}{|c|}{$\begin{array}{c}10.5 \\
42\end{array}$} & \multicolumn{2}{|c|}{$\begin{array}{c}10.5 \\
72\end{array}$} \\
\hline 性 & 別 & $\hat{o}$ & 우 & $\hat{\sigma}$ & 우 & $\hat{o}$ & 우 & $\hat{o}$ & 우 & 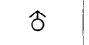 & 우 \\
\hline 4 週令 & $\begin{array}{ll}\text { 羽 } & \text { 数 } \\
\text { 初 体 重 } \mathrm{g}\end{array}$ & $\begin{array}{r}46 \\
420\end{array}$ & $\begin{array}{r}46 \\
375\end{array}$ & $\begin{array}{r}46 \\
417\end{array}$ & $\begin{array}{r}46 \\
383\end{array}$ & $\begin{array}{r}46 \\
404\end{array}$ & $\begin{array}{r}46 \\
386\end{array}$ & $\begin{array}{r}46 \\
394\end{array}$ & $\begin{array}{r}46 \\
373\end{array}$ & $\begin{array}{r}46 \\
402\end{array}$ & $\begin{array}{r}46 \\
38\end{array}$ \\
\hline 10週令 & $\begin{array}{ll} & \text { 数 } \\
\text { 終 体重 } \mathrm{g} \\
\text { 育 成 率 } \%\end{array}$ & $\begin{array}{r}44 \\
1,843 \\
96\end{array}$ & $\begin{array}{r}44 \\
1,510 \\
96\end{array}$ & $\begin{array}{r}46 \\
1,917 \\
100\end{array}$ & $\begin{array}{r}46 \\
1,554 \\
100\end{array}$ & $\begin{array}{r}43 \\
1,868 \\
94\end{array}$ & $\begin{array}{r}46 \\
1,589 \\
100\end{array}$ & $\begin{array}{r}46 \\
1,864 \\
100\end{array}$ & $\begin{array}{r}46 \\
1,561 \\
100\end{array}$ & $\begin{array}{r}46 \\
1,892 \\
100\end{array}$ & $\begin{array}{r}46 \\
1,498 \\
10\end{array}$ \\
\hline $\begin{array}{c}4 \sim 10 \\
(6 \text { 週令 } \\
\text { 週間 })\end{array}$ & $\begin{array}{l}\text { 増体量 } \mathrm{g} \\
\text { 同上指 数 } \\
\text { 飼料掑取量 } \mathrm{g} \\
\text { 飼料要求率 }\end{array}$ & $\begin{array}{r}1,27 \\
9 \\
4,20\end{array}$ & 26 & $\begin{array}{r}1,33 \\
10 \\
4,12\end{array}$ & 3.09 & $\begin{array}{r}1,33 \\
10 \\
4,16\end{array}$ & 12 & $\begin{array}{r}1,32 \\
10 \\
4,1\end{array}$ & 10 & $\begin{array}{r}1,30 \\
9 \\
4,15\end{array}$ & $\begin{array}{l}5 \\
8 \\
5 \\
3.19\end{array}$ \\
\hline $\begin{array}{l}\text { 屠 } \\
\text { 体 } \\
\text { 分 }\end{array}$ & $\begin{array}{l}\text { 技肉歩留\% } \\
\text { 可食内臟 \% } \\
\text { 精肉歩留\% }\end{array}$ & & & & & & & & & & \\
\hline
\end{tabular}

育成率は 4 週令から 10 週令までの数值

表 7 愛知, 長崎, 岡山の 3 場の成績の分散分析表

\begin{tabular}{|c|c|c|c|c|c|c|c|}
\hline \multirow{2}{*}{ 要 } & \multirow{2}{*}{ 因 } & \multirow[b]{2}{*}{ 自 由 度 } & \multicolumn{2}{|r|}{ 散 } & \multirow[b]{2}{*}{ 自 } & \multirow[b]{2}{*}{ 由 度 } & \multirow{2}{*}{$\frac{\text { 分 散 }}{\text { 飼料要求率 }}$} \\
\hline & & & 增体量 & 育成率 & & & \\
\hline 飼 料 & 間 (D) & 4 & 836 & 4.5 & & 4 & 0.0015 \\
\hline 場 & 間 (L) & 2 & $102,453^{* *}$ & 0.4 & & 2 & $0.0709 * *$ \\
\hline 性 & 間 $(S)$ & 1 & $463,266^{* *}$ & 8.5 & & & \\
\hline D & $\times \quad \mathrm{L}$ & 8 & 1,601 & 2.7 & & 8 & 0.0047 \\
\hline $\mathrm{D}$ & $\times \mathrm{S}$ & 4 & 434 & 1.8 & & & \\
\hline L & $\times \quad \mathrm{S}$ & 2 & $11,661^{* *}$ & 0.1 & & & \\
\hline 誤差（1 & $\mathrm{D} \times \mathrm{L} \times \mathrm{S})$ & 8 & 559 & 3.4 & & & \\
\hline
\end{tabular}

**危険率 $1 \%$

互作用効果も有意とはい充なかった。この結果は, 飼料 中のリボフラビンとニュチン酸含量をビタミン添加剂 1 号を配合した試験飼料 1 の，それぞれ 2.6 および 42 $\mathrm{mg} / \mathrm{kg}$ 以上にしても特別な効果が期待できないことを 示しており,これ洛各場とも, また雄, 雌ともに共通し ていえることである。また，表 7 には示さなかったが， ブロイラー歩留（枝肉十可食内臓の歩留）打よび精肉歩 留についても飼料間差は有意とはいえなかった。

兵庫種畜牧場における試験成績を表 8 亿をとめて示し た。この試験では, 3 種類の試験飼料に, 40 羽を 1 区 とする試験区を 2 区ずつ割当てる, 繰返しのある一元配 置法の実験計画を 1 次試験とし，その各試験区を 4 分割
して 2 次試験区とし， 2 系統の $\mathrm{WC} \times \mathrm{WR}$ の雄, 雌各 10 羽ずつを割当てる分割区法101による実験計画となっ ている。表 8 の成績は, 1 次試験区ごとに成績をまとめ て示している。飼料㧌取量の測定が 1 次試験区ごとにな されているので, 飼料要求率については, 1 次試験につ いてのみ検討できるが, 増体量については 1 次・2 次試 験を含めて分散分析できる。分散分析の結果は, 表 9 の ようになった。增体量については，系統別と性別による 差は認められるが，飼料による差は認められなかった。 飼料・系統掞よび飼料・性別の各交互作用は認められな いので, 系統, 性別にかかわらず, 飼料による差はない ものといえるであろう。 
表 8 兵庫種畜牧場における試験成績（鷂種 $\mathrm{WC} \times \mathrm{WR}$ )

試験期間：昭和 41 年 8 月 2 日 眧和 41 年 10 月 12 日

\begin{tabular}{|c|c|c|c|c|c|c|c|c|}
\hline 飼 & 料 & 番 号 & \multicolumn{2}{|c|}{0} & \multicolumn{2}{|c|}{1} & \multicolumn{2}{|c|}{3} \\
\hline 試 & 験 & 区 番 号 & $0-1$ & $0-2$ & $1-1$ & $1-2$ & $3-1$ & $3-2$ \\
\hline $\begin{array}{l}\text { リボ } \\
=コ\end{array}$ & $\begin{array}{l}\text { フラ } \\
\text { チ }\end{array}$ & $\begin{array}{ll}\text { 酸 } & \mathrm{mg} / \mathrm{kg} \\
\mathrm{mg} / \mathrm{kg}\end{array}$ & $\begin{array}{l}1.4 \\
38\end{array}$ & 同 左 & $\begin{array}{l}2.6 \\
42\end{array}$ & 同 左 & $\begin{array}{l}6.9 \\
53\end{array}$ & 同 左 \\
\hline 4 週 & 令 & $\begin{array}{l}\text { 羽 }{ }^{\text {数 }} \text { 初体重 }{ }^{\mathrm{g}}\end{array}$ & $\begin{array}{r}39 \\
594\end{array}$ & $\begin{array}{r}39 \\
583\end{array}$ & $\begin{array}{r}39 \\
571\end{array}$ & $\begin{array}{r}40 \\
598\end{array}$ & $\begin{array}{r}40 \\
585\end{array}$ & $\begin{array}{r}39 \\
579\end{array}$ \\
\hline 10 週 & 令 & $\begin{array}{l}\text { 羽 数 } \\
\text { 終 体 重 } \mathrm{g} \\
\text { 飼料消費量 } \mathrm{g}\end{array}$ & $\begin{array}{r}39 \\
2,082 \\
4,236\end{array}$ & $\begin{array}{r}38 \\
2,128 \\
4,382\end{array}$ & $\begin{array}{r}39 \\
2,073 \\
4,126\end{array}$ & $\begin{array}{r}40 \\
2,182 \\
4,422\end{array}$ & $\begin{array}{r}40 \\
2,131 \\
4,284\end{array}$ & $\begin{array}{r}39 \\
2,106 \\
4,264\end{array}$ \\
\hline $4-10$ & 週 & $\begin{array}{l}\text { 増 体 量 } \mathrm{g} \\
\text { 同上指 数 } \\
\text { 飼料要求率 } \\
\text { 育 成 率\% }\end{array}$ & $\begin{array}{c}1,488 \\
100 \\
2.85 \\
100\end{array}$ & $\begin{array}{c}1,545 \\
100 \\
2.84 \\
97.4\end{array}$ & $\begin{array}{c}1,502 \\
101 \\
2.75 \\
100\end{array}$ & $\begin{array}{c}1,584 \\
103 \\
2.79 \\
100\end{array}$ & $\begin{array}{c}1,546 \\
104 \\
2.77 \\
100\end{array}$ & $\begin{array}{c}1,527 \\
99 \\
2.78 \\
100\end{array}$ \\
\hline 屠体成 & & $\begin{array}{l}\text { 技肉歩留\% } \\
\text { 可食内臓\% } \\
\text { 精肉歩留\% }\end{array}$ & $\begin{array}{r}69.5 \\
4.1 \\
50.7\end{array}$ & $\begin{array}{r}69.5 \\
4.1 \\
51.4\end{array}$ & $\begin{array}{r}72.0 \\
4.2 \\
51.8\end{array}$ & $\begin{array}{r}70.5 \\
3.8 \\
52.5\end{array}$ & $\begin{array}{r}69.9 \\
4.1 \\
51.2\end{array}$ & $\begin{array}{r}70.1 \\
3.8 \\
52.6\end{array}$ \\
\hline
\end{tabular}

表 9 兵庫における成績の分散分析結果

\begin{tabular}{|c|c|c|c|c|}
\hline \multirow{2}{*}{ 要 } & \multicolumn{2}{|c|}{ 增 体 量 } & \multicolumn{2}{|c|}{ 飼料要求率 } \\
\hline & 自由度 & 分 散 & 自由度 & 分 散 \\
\hline \multicolumn{5}{|l|}{1 次試験 } \\
\hline 飼 料 (D) & 2 & 2,210 & 2 & $0.0035^{*}$ \\
\hline 1 次誤差 (e $\left.e_{1}\right)$ & 3 & $51,940^{1)}$ & 3 & 0.0003 \\
\hline \multicolumn{5}{|l|}{2 次試験 } \\
\hline 系 統 (B) & 1 & $389,301 * *$ & & \\
\hline 性 別 (S) & 18 , & $, 926,833^{* *}$ & & \\
\hline $\mathrm{D} \times \mathrm{B}$ & 2 & 8,094 & & \\
\hline $\mathrm{D} \times \mathrm{S}$ & 2 & 20,236 & & \\
\hline $\mathrm{B} \times \mathrm{S}$ & 1 & 96,267 & & \\
\hline $\mathrm{D} \times \mathrm{B} \times \mathrm{S}$ & 2 & 5,853 & & \\
\hline 2 次誤差 $\left(\mathrm{e}_{2}\right)$ & 9 & $21,491^{1)}$ & & \\
\hline 個体差（i ） & 192 & 10,147 & & \\
\hline
\end{tabular}

* 危険率 $5 \%$ ， **危険率 $1 \%$

1) $e_{1}, e_{2}$ は $\mathrm{i}$ に対し, 有意，(危険率それぞれ $5 \%$ と $1 \%$ )

飼料要求率については, 飼料問差が有意であって, リ ボフラビン, ニコチン酸ともに無添加の添加剤 0 号配合 区の飼料要求率が他の 2 区の飼料要求率より大きくなっ ていることが示された。したがって, 飼料要求率の面か らは, リボフラビンとニコチン酸を添加したほうがよい といえる。ブロイラー歩留および精肉歩留については, 飼料間差は有意とはいえなかった。
考

愛知, 長崎, 岡山の 3 試験場において実施した実験の 結果から，ブロイラー仕上用飼料中のリボフラビンと二 コチン酸の含量は，1 $\mathrm{kg}$ 中それぞれ $7.2 \mathrm{mg}$ と $42 \mathrm{mg}$ より少なくてもよいことが確かめられた。これらの含量 は, 3 週令宋での期間に必要であることが確認された量 であって，この知見は，4週令頃を境界として，ある種 の栄養素の要求量が大きく変化するという著者らの見 解 4 ,5) を支持するものといえるであるう。 3 試験場にお ける実験結果は，兵庫種畜牧場における実験からも支持 されており，試験飼料 1 と 3 を与えた 4 試験区の成績は ほぼ同じ成績であって，差があるとはいえないので，試 験飼料 3 に含まれているビタミン含量より少ない量でも よいことが示されている。

これら 4 試験場における成績から, リボフラビンとニ コチン酸の含量が，試験飼料 1 に含まれている $2.6 \mathrm{mg}$ と $42 \mathrm{mg}$ であれば， 4 週令以後のブロイラーヒナに与え て問題はないといえるであろう。この結論は,ブロイラ 一の鶏種, 系統の相違や性別に関係なく適用できると考 えられる。

しかしながら，兵庫種畜牧場における試験飼料 0 の給 与区の成績によれば,体重には大差のない結果であるが, 飼料要求率に有意差が認められている。飼料要求率は 1 $\mathrm{kg}$ 増体に要する飼料の $\mathrm{kg}$ 量であるが, 試験飼料 0 を 与えると, $1 \mathrm{~kg}$ 増体にあたり平均 $2.845 \mathrm{~kg}$ を要するこ 
とになり, 試験飼料 2,3 の場合の平均 $2.773 \mathrm{~kg}$ を要 するのに比して, 約 $60 \mathrm{~g}$ 多くの飼料を消費する計算に なる。試験飼料 0 には, リボフラビンとニコチン酸を添 加していないので, そのリボフラビン, ニコチン酸含量 はすべて天然飼料に由来するものであるが，これらのビ タミンを全く添加しないで与えることは避けたほうがよ いといえるであろう。このような飼料要求率改善に対与 る効果が, どちらのビタミンによるものであるか, ある いは複合効果であるかという問題は, 今後の研究課題で あろう。

\section{要 約}

兵庫種畜牧場, 愛知県養䳕試験場, 長崎県養䳕センタ ーおよび岡山県養鵎試験場の 4 試験場において, 白色コ ーニッシュ種雄に 3 種類の䧳を交配してえた 3 種類の一 代雑種ヒナ合計 1,740 羽を用いて，ブロイラ一仕上用飼

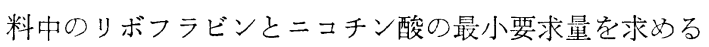
目的で飼養試験を行った。

その結果, 天然の飼料原料を配合した基礎飼料に，1 $\mathrm{kg}$ あたり, リボフラビン $1.2 \mathrm{mg}$, ニコチン酸 $4 \mathrm{mg}$ 添加して給与すれば, 増体量, 飼料要求率, ブロイラー 歩留および精肉歩留において，ビタミンをこれ以上に多 く添加して与えたヒナの成績に比して差のない結果であ った。基礎飼料には, リボフラビンとニコチン酸を, そ れぞれ $1.4 \mathrm{mg} / \mathrm{kg}$ と $38 \mathrm{mg} / \mathrm{kg}$ 含えでいるので, 上記 の飼料中の含量は, それぞれ $2.6 \mathrm{mg} / \mathrm{kg}$ と $42 \mathrm{mg} / \mathrm{kg}$ となる。

基礎飼料にリボフラビンとニコチン酸を添加しない場
合には，発育には大きな差が認められないにもかかわら ず, 飼料要求率が增大して不利であった。

謝辞

本研究の立案, 実施にあたり, 下記の方々の御指導, 御協力を頂いたの で,ここに記して深苴な謝意を表する。(敬称は略す)

星井 博・ 小坂清已 (畜産試䮦場)

堀切充幸・出田午郎・清水徽三・恩田正臣・ 丸尾宏章・鶴見界三 (兵庫種畜牧場)

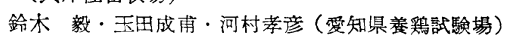

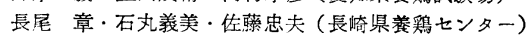

川崎 晃・多田昌男・松井修 (岡山県養鶟試験場)

また，飼料中のリボフラビン,ニコチン酸の测定を伎賴した武田科学埕 料 K.K. に感謝する。

\section{引用文献}

1) 吉田 実・星井 博 ・ 森本 宏: ビタミン, 28, 225, 1963.

2）吉田 実・星井 博・森本 宏：同上， 28，230， 1963.

3) Yoshida, M., H. Hoshil and H. Morimoto: Poultry Sci., 45, 736, 1966.

4) 吉田 実・森本 宏：畜産試験場特別報告, No. 8 第 6 章, 112 頁, 1967.

5）吉田 実・星井博・森本 宏：家禽会誌，4，117, 1967.

6）森本宏他：畜産試験場特別報告, No. 7, 第 2 章, 24 頁, 1966.

7) 吉田 実・水谷一之, 中山泰夫, 高橋 彰: 家禽 会誌, 4, 123, 1967

8）森本 宏：畜産試験場特別報告, No. 8, 第 7 章, 126 頁, 1967.

9）鈴木友二・村岡三郎：ビタミン，アミノ酸の微生 物定量法, 南山堂, 東京 (1956).

10) SNEDECOR, G.W.: 統計的方法 (改訂版) 畑村 - 奥 野・津村共訳, p. 332, 岩波書店, 東京, 1963. 


\title{
Requirements of Riboflavin and Nicotinic Acid for Broiler-type Chicks after 4 Weeks of Age
}

\author{
Minoru Yoshida*, Katsuji Fujioka**, Kazuyuki Mizutani***, \\ Hazime Hirashima****, and Akira Takahashi***** \\ *National Institute of Animal Industry, Chiba-shi. \\ **Hyogo Animal Breeding Station, Tatsuno-shi, Hyogo-ken. \\ ***Aichi Prefectural Poultry Experiment Station, Kiyosu-machi, Aichi-ken. \\ ****Omura Poultry Center, Omura-shi, Nagasaki-ken. \\ *****Okayama Prefectural Poultry Experiment Station, Okayama-shi.
}

Three experiments were carried out at 3 local experiment stations with one of 3 broilertype cross-breds for each station and one experiment at Hyogo Animal Breeding Station with cross-breds of White Cornish male $\mathrm{x}$ White Plymouth Rock female.

In 3 local stations, 5 groups of 4 -week-old chicks were fed one of 5 experimental broiler finisher diets containing various levels of riboflavin and nicotinic acid for 6 weeks. Growth rate, feed conversion (feed/gain) and ratios of ready-to-cook and chicken meat of chicks on the finisher containing the lowest levels of riboflavin and nicotinic acid, i.e. 2.6 and $42 \mathrm{mg} / \mathrm{kg}$, respectively, were almost identical to those of chicks fed the other 4 experimental diets.

In Hyogo Animal Breeding Station, duplicated lots of 40 4-week-old chicks each were fed 3 experimental broiler finisher for 6 weeks. One finisher containined no additional riboflavin and nicotinic acid, the second had the same levels of the vitamins to the diet of the lowest levels of the vitamins in the previous experiments. The last finisher was the control diet containing excess amount of the vitamins. Performance of the chicks on the second diet was almost identical to that on the diet of excess vitamins, confirming the results cbtained in the previous experiments at 3 stations. Growth rate and ratios of ready-to-cook and chicken meat of chicks on the finisher without the additional vitamins were almost equal to those of the other chicks, but feed conversion was slightly but significantly inferior to those of the other 2 groups.

With these experimental results, it was suggested that the minimum requirement of riboflavin and nicotinic acid for broiler-type chicks after 4-week-old will be not more than 2.6 and $42 \mathrm{mg} / \mathrm{kg}$ diet, respectively. (Japan. Poultry Sci., 4, 129, 1967) 